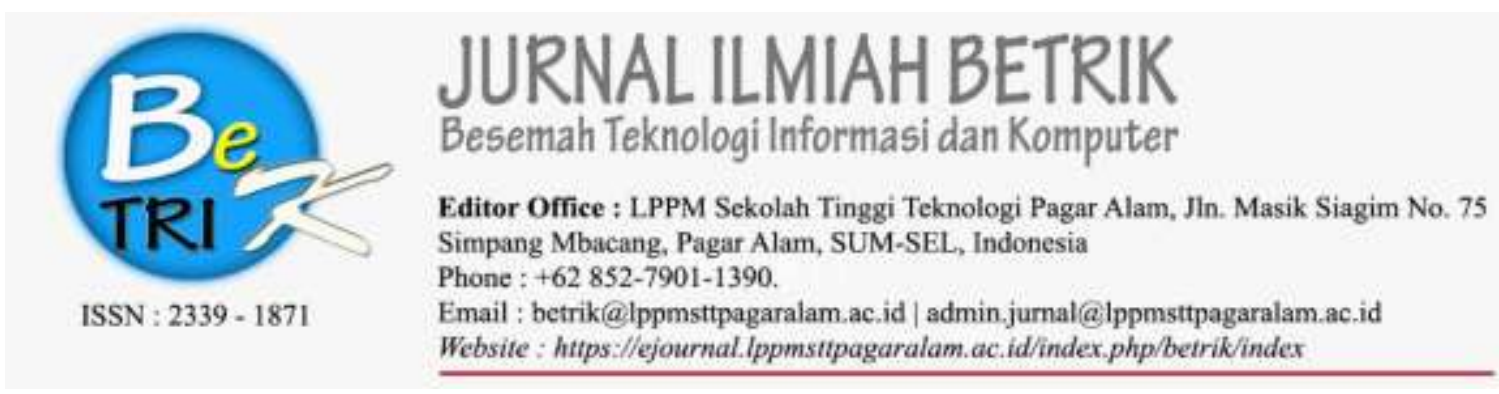

\title{
SISTEM INFORMASI PENDATAAN PENGUNJUNG PERPUSTAKAAN (Studi kasus : SMKN 1 PALEMBANG)
}

\author{
Imam Solikin ${ }^{1}$, Muhammad Sobri ${ }^{2}$, Riky Adi Saputra ${ }^{3}$ \\ 1, 2, ${ }^{3}$ Program Studi Manajemen Informatika, Fakultas Vokasi,Universitas Bina Darma \\ Jln. Jend. A. Yani No.3 Plaju Palembang \\ Email : imamsolikin@binadarma.ac.id ${ }^{1}$
}

\begin{abstract}
Abstrak : SMKN 1 Palembang merupakan salah satu lembaga pendidikan Sekolah Menengah Kejuruan Negeri yang merupkan sekolah unggulan di kota Palembang. Perpustakaan pada sekolah ini dilakukan menggunakan microsoft excel dan papan tulis dimana pemakaian tersebut kurang efisien dan belum tersedia sistem informasi pendataan pengunjung perpustakaan. Berdasarkan permasalahan tersebut maka perlu adanya pembuatan sistem berbasis web yaitu sistem informasi pendataan pengunjung perpustakaan. Metode yang digunakan dalam pembuatan sistem ini adalah menggunakan Model air terjun (waterfall) sering juga disebut model sekuensial linier (sequential linear) atau alur hidup klasik (classic life cycle). Adapun tahapan dari model ini adalah analisis, desain, pengodean, pengujian, dan tahap pendukung (support). Tujuan dari penelitian ini adalah untuk mempermudah dalam pendataan, pencarian data pengujung perpustakaan sehingga pekerjaan menjadi lebih efesien. Kata Kunci : lembaga pendidikan, sistem informasi, pendataan, perpustakaan, waterfall
\end{abstract}

Abstract: SMKN 1 Palembang is one of the State Vocational High School educational institutions which is the flagship school in the city of Palembang. The library at this school is done using Microsoft Excel and the blackboard where the usage is less efficient and there is no information system for library visitor data collection. Based on these problems, it is necessary to create a web-based system, namely the library data collection information system. The method used in making this system is to use the waterfall model, often referred to as a linear sequential model (classic life cycle). The stages of this model are analysis, design, coding, testing, and supporting stages. The purpose of this study is to facilitate data collection, search for library end data so that the work becomes more efficient

Keywords: education institute, information system, data collection, library, waterfall

\section{PENDAHULUAN}

Perkembangan ilmu teknologi dan informasi yang berkembang saat ini sangat pesatnya sehingga membuat kita untuk tidak ketinggalan mengikuti kemajuan teknologi informasi. Kemajuan tersebut menghasilkan manfaat yang baik untuk mendorong percepatan berbagai bidang, termasuk lembaga dan instansi. Seiring dengan perkembangan teknologi yang begitu pesat, kebutuhan akan informasi sangat diperlukan, sehingga mempermudah pengguna (user) dalam melakukan suatu pekerjaan. 
SMKN 1 Palembang adalah satu diantara lembaga pendidikan Sekolah Menengah Kejuruan Negeri di Kota Palembang, sebagai satu diantara sekolah unggulan di Kota Palembang, sekolah ini belum memiliki sistem informasi dalam pendataan anggota pengunjung perpustakaan dan pengolahan data statistik pengunjung perpustakaan. Saat ini masih menggunakan microsoft excel dan papan tulis dimana pemakaian tersebut kurang efisien atau masih secara manual.

Dengan dibuatnya suatu sistem informasi mengenai statistik perpustakaan berbasis web agar mempermudah petugas perpustakaan dalam pengolahan data, dan pembuatan laporan selain itu juga sistem yang dibentuk berbasis web, kita ketahui bahwa keunggulan dari sistem informasi berbasis web yang patut dipertimbangkan adalah antarmuka yang fleksibel, keamanan data lebih terjaga dan bisa di sambungkan ke webserver.

Untuk mengatasi permasalahan diatas, maka dibuat suatu sistem informasi statistik pengunjung perpustakaan menggunakan bahasa pemrograman $P H P$ dan database MySQL untuk digunakan dalam pengolahan, penyimpanan, pemcarian dan pembuatan laporan pengunjung perpustakaan. Berdasarkan latar belakang yang ada, maka diangkatlah penelitian ini degan judul "Sistem informasi statistik pengunjung perpustakaan SMKN 1 Palembang".
Rumusan masalah dalam penelitian ini adalah membangun sistem sistem informasi statistik pengunjung perpustakaan SMKN 1 Palembang. Tujuan dari penelitian ini adalah mempermudah dalam pendataan, pencarian data pengujung perpustakaan sehingga pekerjaan menjadi lebih efesien.

\section{METODELOGI PENELITIAN}

\subsection{Sistem}

Menurut ( Jogiyanto :2005 ), Sistem adalah suatu jaringan kerja dari prosedurprosedur yang saling berhubungan, berkumpul bersama-sama untuk melakukan suatu kegiatan atau untuk menyelesaikan suatu sasaran yang tertentu. Menurut (Edhy Sutanta : 2009), Sistem secara umum dapat didefinisikan sebagai kumpulan hal atau elemen yang saling bekerja sama atau yang dihubungkan dengan cara-cara tertentu sehingga membentuk satu kesatuan untuk melaksanakan suatu fungsi untuk mencapai suatu tujuan. Sistem mempunyai karakteristik atau sifat - sifat tertentu, yaitu : Komponen Sistem, Batasan Sistem, Lingkungan Luar Sistem, Penghubung Sistem, Masukan Sistem, Keluaran Sistem, Pengolahan Sistem dan Sasaran Sistem.

\subsection{Informasi}

Menurut (George H. Bodnar : 2000), Informasi adalah data yang diolah sehingga dapat dijadikan dasar untuk mengambil keputusan yang tepat. Menurut (Husein : 2004), informasi adalah data yang telah diolah menjadi suatu bentuk yang mempunyai arti dan manfaat bagi manusia.

\subsection{Sistem Informasi}


Menurut (Kertahadi : 2007), Sistem informasi adalah alat untuk menyajikan informasi sedemikian rupa sehingga bermanfaat bagi penerimanya. Tujuannya adalah untuk memberikan informasi dalam perencanaan, memulai, pengorganisasian, operasional sebuah perusahaan yang melayani sinergi organisasi dalam proses mengendalikan pengambilan keputusan. Menurut (Tata Sutabri : 2005), Sistem informasi merupakan suatu sistem di dalam suatu organisasi yang mempertemukan kebutuhan pengolahan transaksi harian yang mendukung fungsi organisasi yang bersifat manajerial dalam kegiatan strategi dari suatu organisasi untuk dapat menyediakan kepada pihak luar tertentu dengan laporan - laporan yang diperlukan.Menurut (Hanif Al Fatta : 2009), Sistem informasi merupakan suatu perkumpulan data yang terorganisasi beserta tatacara penggunaanya yang mencangkup lebih jauh dari pada sekedar penyajian. Istilah tersebut menisyaratkan suatu maksud yang ingin dicapai dengan jalan memilih dan mengatur data serta menyusun tatacara penggunaanya.

\subsection{Website}

(Hakim Lukmanul : 2004), Website merupakan fasilitas internet yang menghubungkan dokumen dalam lingkup lokal maupun jarak jauh. Dokumen pada website disebut dengan web page dan link dalam website memungkinkan pengguna bisa berpindah dari satu page ke page lain (hyper text), baik diantara page yang disimpan dalam server yang sama maupun server diseluruh dunia. Pages diakses dan dibaca melalui browser seperti Netscape Navigator, Intiernet Explorer, Mozila Firefox, Google Chrome dan aplikasi browser lainnya. Menurut (Taufiq Hidayatullah : 2002), Website adalah bagian paling terlihat sebagai jaringan terbesar dunia, yakni internet. Menurut (Suwanto Raharjo : 2004), Website adalah salah satu layanan internet yang paling banyak digunakan dibanding dengan layanan lain seperti ftp, gopher, news atau bahkan email.

\subsection{DFD (Data Flow Diagram)}

(Wijaya : 2007) Data flow Diagram merupakan gambaran grafis yang memperlihatkan aliran data dari sumbernya dalam obyek kemudian melewati suatu proses yang mentransformasikan ke tujuan yang lain, yang ada pada objek lain.Menurut (Kristanto : 2003), Data Flow Diagram (DFD) merupakan suatu model logika data atau proses yang dibuat untuk menggambarkan dari mana asal data dan kemana tujuan data yang keluaran dari sistem, dimana data di simpan, proses apa yang menghasilkan data tersebut, dan interaksi antara data yang tersimpan dan proses yang dikenakan pada data tersebut. Menurut (Jogiyanto Hartono : 2005), Data Flow Diagram (DFD) merupakan Diagram yang menggunakan notasi simbol untuk menggambarkan arus data system. Simbol-simbol data flow diagram (DFD) 


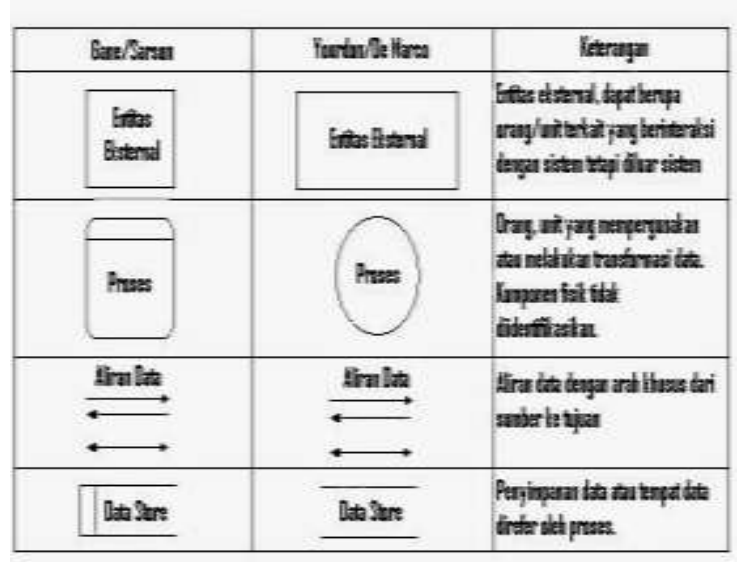

Gambar 1. DFD (data flow diagram)

\subsection{Entity Relationship Diagram (ERD)}

Menurut (Sutanta : 2011), dalam bukunya yang berjudul "Basis Data Dalam Tinjauan Konseptual" menjelaskan bahwa Entity Relationship Diagram (ERD) merupakan suatu model data yang dikembangkan berdasarkan objek.

Menurut (Mata-Toledo dan Cushman: 2007) Mendefenisikan Entity Relationship Diagram (ERD) merupakan representasi grafis dari logika database dengan menyertakan deskripsi detail mengenai seluruh entitas (entity), hubungan (relationship), dan batasan (constraint).

Menurut (Brady dan Loonam : 2010), Entity Relationship diagram (ERD) merupakan teknik yang digunakan untuk memodelkan kebutuhan data dari suatu organisasi, biasanya oleh Sistem Analis dalam tahap analisis persyaratan proyek pengembangan sistem.

Simbol-simbol ERD (Entity Relationship Diagram)

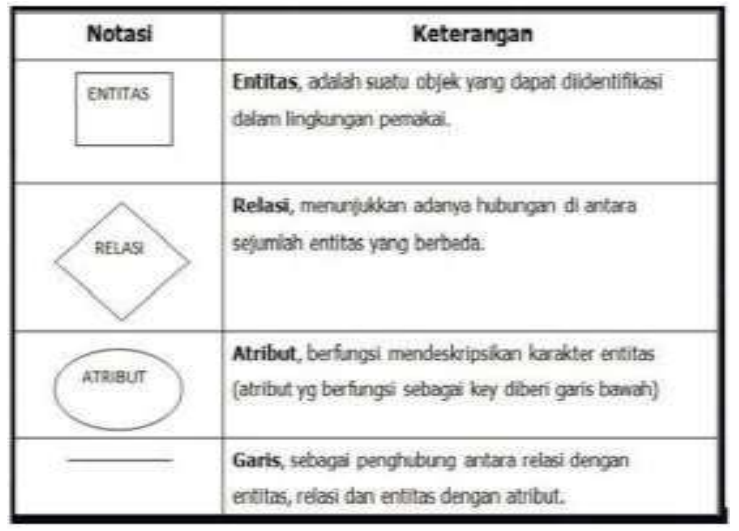

Gambar 2. Simbol ERD (Entity Relationship

Diagram)

\subsection{Metode Pengumpulan Data}

Menurut (Sugiyono : 2013) teknik pengumpulan data merupakan langkah yang paling strategis dalam penelitian, karena tujuan utama dari penelitian adalah mendapatkan data.

1. Teknik Wawancara, Menurut Esterberg dalam Sugiyono (2013:231) wawancara merupakan pertemuan dua orang untuk bertukar informasi dan ide melalui tanya jawab, sehingga dapat dikontruksikan makna dalam suatu topik tertentu.

2. Teknik Pengamatan/Observasi, Sutrisno Hadi dalam Sugiyono (2013:145) mengemukakan bahwa, observasi merupakan suatu proses yang kompleks, suatu proses yang tersusun dari berbagai proses biologis dan psikhologis. Dua di antara yang terpenting adalah proses-proses pengamatan dan ingatan.

3. Teknik Dokumentasi, Menurut Sugiyono (2013:240) dokumen merupakan catatan peristiwa yang sudah berlalu. Dokumen bisa berbentuk tulisan, gambar, atau karyakarya monumental dari seorang. Dokumen 
yang berbentuk tulisan misalnya catatan harian, sejarah kehidupan (life histories), ceritera, biografi, peraturan, kebijakan. Dokumen yang berbentuk gambar misalnya foto, gambar hidup, sketsa dan lain-lain. Dokumen yang berbentuk karya misalnya karya seni, yang dapat berupa gambar, patung, film dan lain-lain. Studi dokumen merupakan pelengkap dari penggunaan metode observasi dan wawancara dalam penelitian kualitatif.

\subsection{Metode Pengembangan Sistem}

Menurut Pressman (2015), Model Waterfall adalah Model Air Terjun kadang dinamakan siklus hidup klasik (classic life cyle), dimana hal ini menyiratkan pendekatan yang sistematis dan berurutan (sekuensial) pada pengembangan perangkat lunak. Pengembangan perangkat lunak dimulai dari spesifikasi kebutuhan pengguna dan berlanjut melalui tahapantahapan perencanaan (planning), pemodelan (modeling), konstruksi (construction), serta penyerahan sistem perangkat lunak ke para pelanggan/pengguna (deployment), yang diakhiri dengan dukungan berkelanjutan pada perangkat lunak yang dihasilkan.

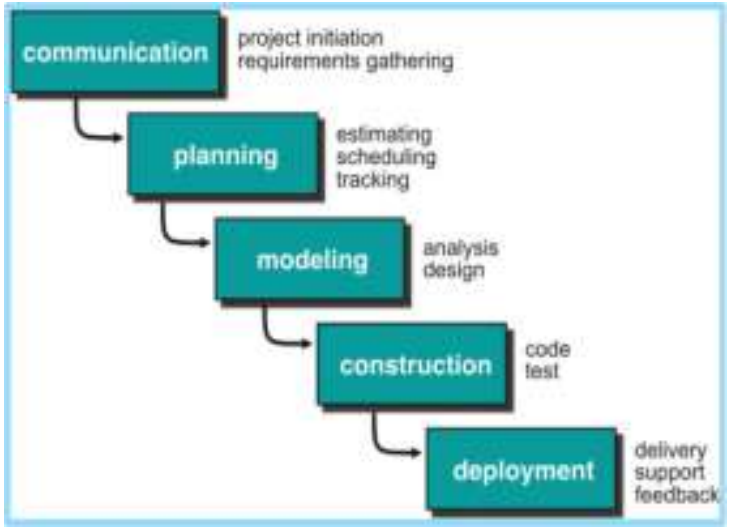

Gambar 3. Model Waterfall

\subsection{Desain ERD (Entity Relationship Diagram)}

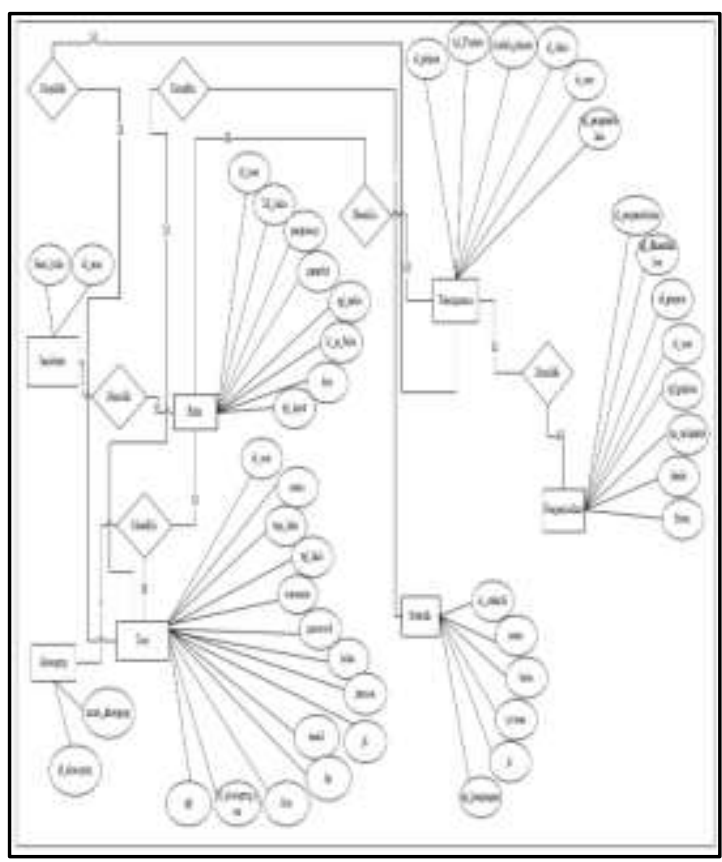




\subsection{Desain DFD (Data Flow Diagram)}

Pada tahapan ini sistem akan dirancang dengan menggunakan Diagram Data Konteks, Data Flow Diagram (DFD) level 0, Data Flow Diagram (DFD) level 1, Entity Relationship Diagram (ERD).

a. Diagram Data Konteks, merupakan gambaran suatu sistem yang dibuat secara umum, namun belum menggambarkan arus data atau penyimpanan data. Untuk lebih jelas harus ke level selanjutnya. Berikut merupakan gambar diagram aliran data konteks :

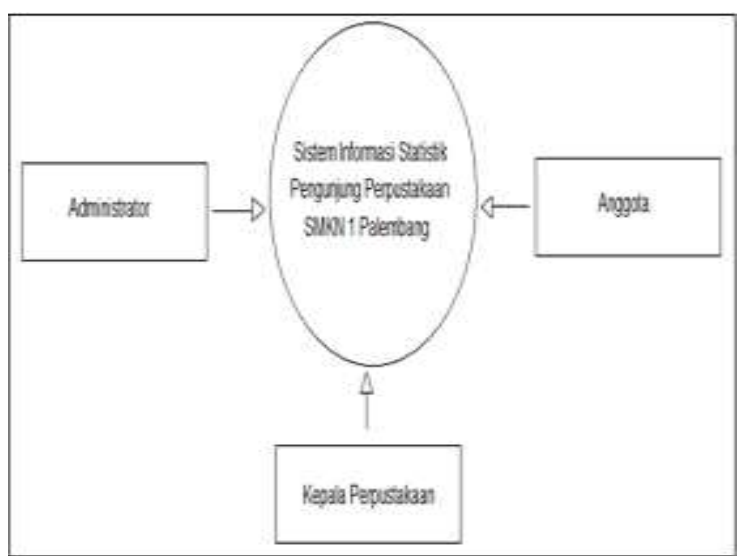

Gambar 5. Diagram Data Konteks

\section{b. Data Flow Diagram (DFD) Level 0}

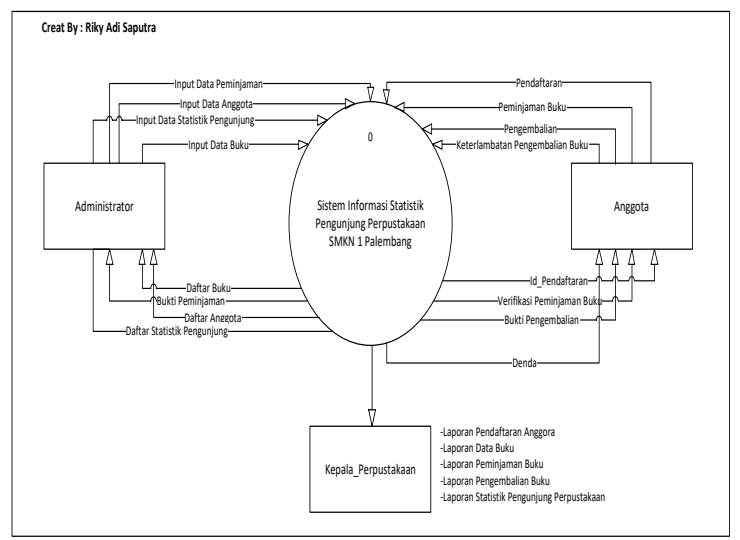

Gambar 6. DFDLevel 0

\subsection{Desain Database}

Dalam rancangan struktur database, dibentuklah database dengan nama dt_si_perpus dan database tersebut telah dirancang menjadi delapan tabel yang akan dimuat kedalam database tersebut yaitu :

a. Tabel Buku

Tabel buku berfungsi sebagai media penyimpanan data buku perpustakaan SMKN 1 Palembang.

Tabel 1. Tabel buku

\begin{tabular}{lllll}
\hline No & NamaField & Type & Size & Keterangan \\
\hline 1 & id_buku & int & 10 & $\begin{array}{l}\text { id buku } \\
\text { *primary } \\
\text { key }\end{array}$ \\
\hline 2 & jdl_buku & varchar & 25 & judul buku \\
\hline 3 & pengarang & varchar & 25 & $\begin{array}{l}\text { nama } \\
\text { pengarang }\end{array}$ \\
\hline 4 & penerbit & varchar & 25 & $\begin{array}{l}\text { nama } \\
\text { penerbit }\end{array}$ \\
\hline 5 & tgl_terbit & date & - & $\begin{array}{l}\text { tanggal } \\
\text { terbit }\end{array}$ \\
\hline 6 & id_jn_buku & varchar & 25 & jenis buku \\
\hline 7 & foto & varchar & 25 & Foto \\
\hline 8 & tgl_input & date & - & $\begin{array}{l}\text { tanggal } \\
\text { input buku }\end{array}$ \\
\hline 9 & jumlah & int & 11 & $\begin{array}{l}\text { jumlah } \\
\text { buku }\end{array}$ \\
\hline & & & &
\end{tabular}

b. Tabel Peminjaman

Tabel data berfungsi sebagai media penyimpanan data peminjaman buku perpustakaan SMKN 1 Palembang.

Tabel 2. Tabel peminjaman

No NamaField Type Size Keterangan


Imam Solikin, Muhammad Sobri dan Riky Adi Saputra

\begin{tabular}{|c|c|c|c|c|}
\hline 1 & id_pinjam & int & 11 & $\begin{array}{l}\text { id } \\
\text { pinjam*prim } \\
\text { ary key }\end{array}$ \\
\hline 2 & tgl_pinjam & date & - & $\begin{array}{l}\text { tanggal } \\
\text { peminjaman } \\
\text { buku }\end{array}$ \\
\hline 3 & $\begin{array}{l}\text { jumlah_pin } \\
\text { jam }\end{array}$ & int & 2 & $\begin{array}{l}\text { jumlah } \\
\text { pinjam }\end{array}$ \\
\hline 4 & Id_buku & $\begin{array}{l}\text { varc } \\
\text { har }\end{array}$ & 25 & judul buku \\
\hline 5 & Id_user & $\begin{array}{l}\text { varc } \\
\text { har }\end{array}$ & 25 & $\begin{array}{l}\text { nama } \\
\text { anggota }\end{array}$ \\
\hline 6 & $\begin{array}{l}\text { tgl_penge } \\
\text { mbalian }\end{array}$ & date & - & $\begin{array}{l}\text { tanggal } \\
\text { pinjam }\end{array}$ \\
\hline
\end{tabular}

c. Tabel Pengembalian

Tabel data berfungsi sebagai media penyimpanan data pengembalian buku perpustakaan SMKN 1 Palembang.

Tabel 4. Tabel pengembalian

\begin{tabular}{lllll}
\hline No & $\begin{array}{l}\text { NamaFiel } \\
d\end{array}$ & Type & Size & Keterangan \\
\hline 1 & $\begin{array}{l}\text { id_penge } \\
\text { mbalian }\end{array}$ & int & 10 & $\begin{array}{l}\text { id } \\
\text { pengembalian } \\
\text { *primary key }\end{array}$ \\
\hline 2 & $\begin{array}{l}\text { tgl_penge } \\
\text { mbalian }\end{array}$ & date & - & $\begin{array}{l}\text { tanggal } \\
\text { pengembalian } \\
\text { buku }\end{array}$ \\
\hline 3 & id_pinjam & int & 10 & id pinjam \\
\hline 4 & id_user & $\begin{array}{l}\text { varc } \\
\text { har }\end{array}$ & 25 & nama anggota \\
\hline 5 & tgl_pinjam & date & - & $\begin{array}{l}\text { tanggal } \\
\text { peminjaman }\end{array}$ \\
\hline 6 & $\begin{array}{l}\text { lm_terlam } \\
\text { bat }\end{array}$ & $\begin{array}{l}\text { varc } \\
\text { har }\end{array}$ & 25 & $\begin{array}{l}\text { lama } \\
\text { terlambat }\end{array}$ \\
\hline 7 & denda & int & 10 & denda buku \\
\hline 8 & status & $\begin{array}{l}\text { varc } \\
\text { har }\end{array}$ & 25 & $\begin{array}{l}\text { status buku } \\
\text { peminjaman }\end{array}$ \\
\hline & & & &
\end{tabular}

d. Tabel Akses Grup

Tabel data berfungsi sebagai media penyimpanan data jenis buku perpustakaan SMKN 1 Palembang.

Tabel 5. Tabel aksesgrup

\begin{tabular}{lllll}
\hline No & NamaField & Type & Size & Keterangan \\
\hline 1 & id_aksesgrup & Int & 10 & $\begin{array}{l}\text { id } \\
\text { aksesgrup* } \\
\text { primary } \\
\text { key }\end{array}$ \\
\hline 2 & $\begin{array}{l}\text { nama_aksesg } \\
\text { rup }\end{array}$ & $\begin{array}{l}\text { Varc } \\
\text { har }\end{array}$ & 25 & nama buku \\
\hline
\end{tabular}

\section{HASIL DAN PEMBAHASAN}

Hasil dari penelitian yang telah dilakukan di sekolah menengah kejuruan Negeri (SMKN) 1 Palembang berupa sistem informasi statistik pengunjung perpustakaan berbasis web.

1. Tampilan halaman depan web

Setelah halaman browser google crome terbuka dan ketikkan url addres "localhost/SI_Perpus/" maka akan tampil halaman depan website berupa halaman login. Halaman login merupakan halaman yang menampilkan akses masuk bagi admin dan user untuk menuju form pageadmin.php san page-siswa.php, yang mana halaman login terdiri dari Username dan Password.

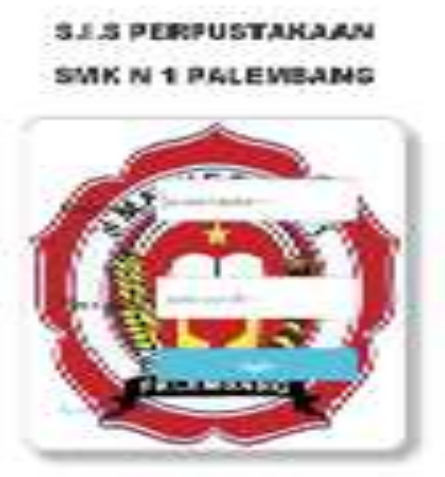

Gambar 6. Halaman depan web

2. Tampilan halaman registrasi 


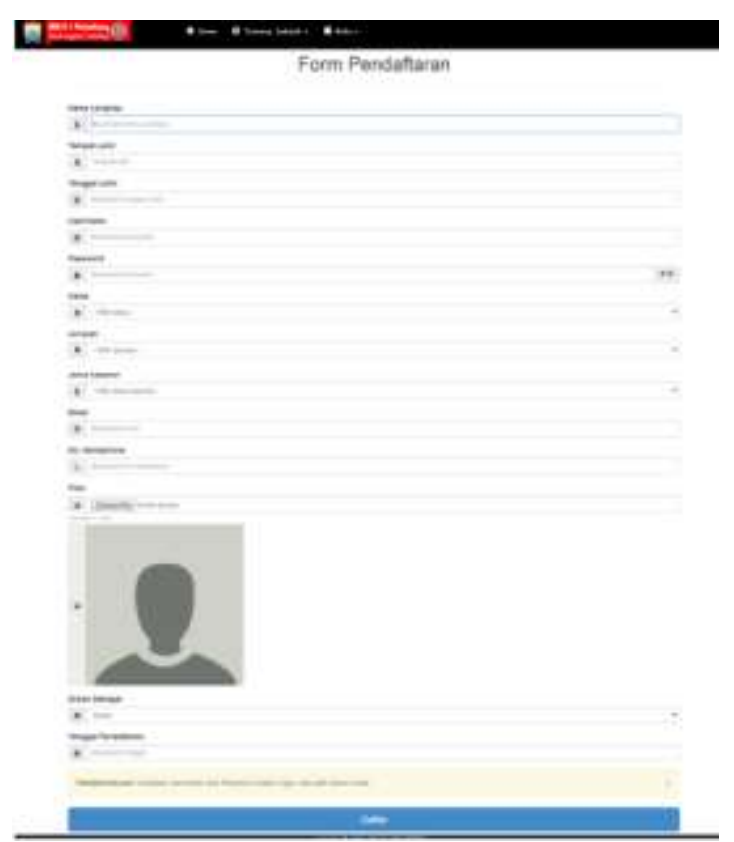

Gambar 7. Halaman registrasi

Setelah siswa (user) mengisi form buku tamu, selanjutnya akan di arahkan ke form registrasi. Tampilan Halaman Registrasi merupakan tampilan halaman yang digunakan untuk mengisi identitas siswa (user) yang akan menjadi anggota perpustakaan SMKN 1 Palembang. Pada halaman ini terdapat tombol daftar apabila siswa (user) calon pendaftar anggota perpustakaan sudah selesai mengisi dengan benar form registrasi dan klik tombol daftar maka secara otomatis data akan tersimpan ke database.

3. Tampilan halaman katalog buku perpustakaan

Tampilan halaman katalog buku perpustakaan digunakan untuk siswa (user) yang ingin melihat buku, dan memilih buku, yang di sarankan sebelum meminjam buku anda harus login terlebih dahulu.

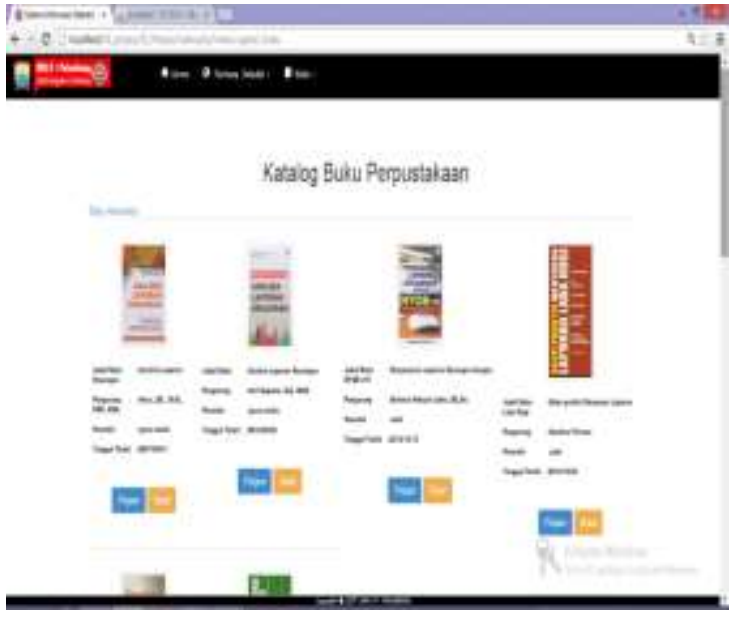

Gambar 8. Halaman katalog buku perpustakaan

4. Tampilan halaman statistik pengunjung

Tampilan halaman statistik pengunjung digunakan untuk menampilkan hasil dari statistik pengunjung perpustakaan dengan jumlah pengunjung berdasarkan tanggal pengunjung perpustakaan pada Sekolah Menengah Kejuruan 1 Palembang.

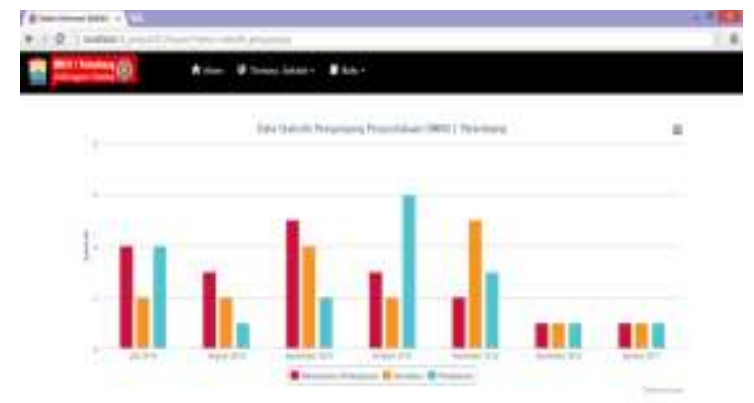

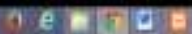

Gambar 9 Halaman statistik pengunjung

5. Tampilan halaman admin website

Tampilan halaman admin website digunakan sebagai panel utama dari form dashboard. Pada halaman ini terdiri dari 7 Halaman panel diantaranya :

a. Halaman Dashboar Admin 

b. Halaman BukuHalaman Proses Buku
c. Halaman Statistik
d. Halaman Laporan
e. Halaman User
f. Halaman Tentang Sistem

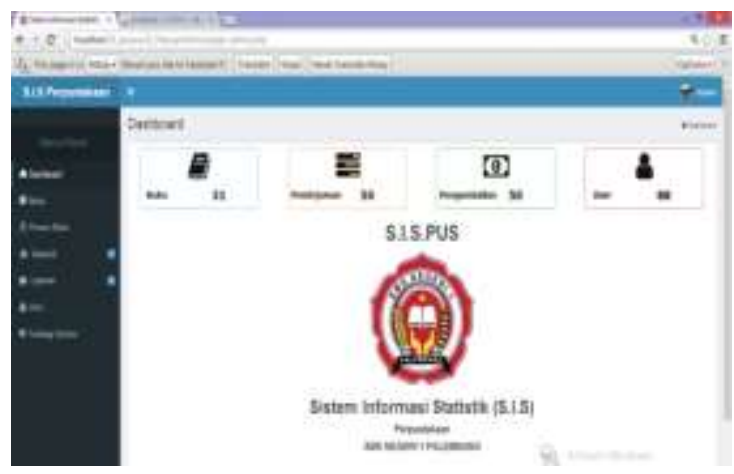

Gambar 10. Halaman utama admin web

6. Tampilan halaman buku admin

Tampilan halaman buku merupakan form yang berada di dashboard admin digunakan untuk menambah data buku, mengubah data buku, menghapus data buku, melihat data buku, laporan data buku, dan statistik data buku.

Pada halaman ini terdapat beberapa tombol diantaranya:

a. Tombol Add berfungsi sebagai tombol untuk menambahkan data buku.

b. Tombol Report berfungsi sebagai tombol untuk menampilkan data yang akan di cetak.

c. Tombol Import berfungsi sebagai tombol untuk mengImport laporan data buku perpustakaan ke file Microsoft Exel. d. Tombol Statistik berfungsi untuk menampilkan statistik data buku yang di inputkan.

e. Tombol cari berfungsi untuk mencari data buku berdasarkan judul buku.

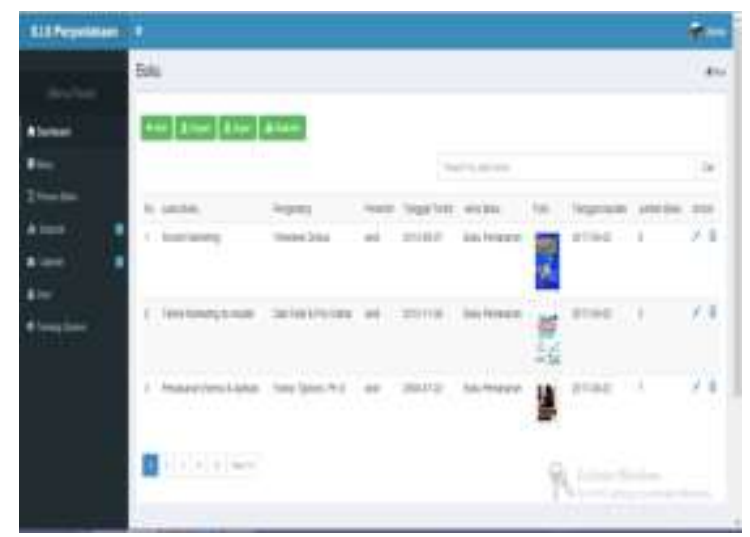

Gambar 11. Halaman buku admin

7. Tampilan statistik peminjaman buku

Tampilan statistik peminjaman buku digunakan untuk menampilkan data statistik peminjaman buku perpustakaan SMKN 1 Palembang.

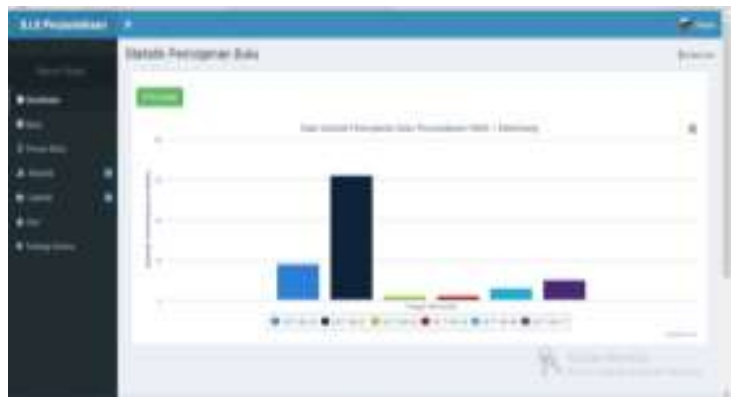

Gambar 12. Statistik peminjaman buku

8. Tampilan data pengembalian buku 


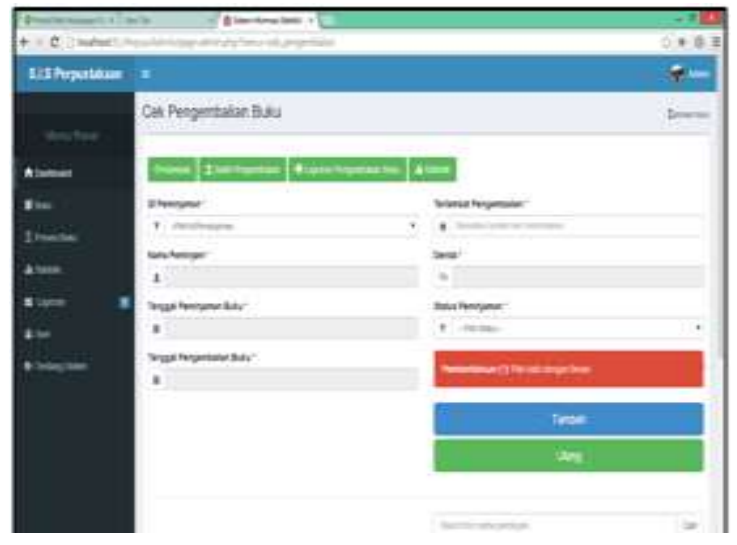

Gambar 13. Data pengembalian buku

Tampilan cek pengembalian buku digunakan untuk menampilkan data pengembalian buku yang sudah dicek berdasarkan tanggal peminjaman dan pengembalian, apabila siswa(user) terlambat mengambalikan maka akan dikenakan denda sebesar Rp.-5.00. /Per hari. Pada halaman ini terdapat tombol bukti pengembalian, laporan pengembalian buku, statistik pengembalian buku.

a. Tombol bukti pengembalian berfungsi sebagai tombol untuk mencetak bukti transaksi pengembalian buku.

b. Tombol laporan pengembalian buku berfungsi sebagai tombol untuk mencetak laporan pengembalian buku perpustakaan SMKN 1 Palembang.

c. Tombol statistik berfungsi sebagai tombol untuk menampilkan data statistik pengembalian buku berdasarkan tanggal dan total peminjaman buku.

\section{KESIMPULAN}

Berdasarkan penelitian yang telah penulis lakukan, maka dapat disimpulkan sebagai berikut:
1. Sistem yang dihasilkan adalah sistem informasi statistik pengunjung perpustakaan di SMKN 1 Palembang berbasis Web.

2. Sistem ini mempunyai fasilitas untuk mendata pengunjung perpustakaan, mempermudah peminjaman dan pengembalian buku perpustakaan serta dapat membantu dalam pembuatan laporan.

3. Sistem ini dapat memudahkan pihak SMKN 1 Palembang dalam pengolahan data statistik pengunjung perpustakaan, data buku dan user, data peminjaman dan pengembalian buku, serta mempermudah membuat laporan.

\section{DAFTAR PUSTAKA}

Al Fatta, Hanif. 2009. Analisis dan Perancangan Sistem Informasi. Yogyakarta: ANDI

Al-Bahra Bin Ladjamudin. 2013. Analisis Dan Desain Sistem Informasi. Graha Ilmu. Yogyakarta

Andri ,Kristanto. 2003.Perancangan Sistem Informasi. Gava Media, Yogyakarta

A.Taufiq Hidayatullah \& Abdul Razaq, 2000,. Berkreasi Dengan Photoshop, PT. Elex Media komputindo, Jakarta

Bodnar, George H., William S. Hopwood, 2000. Sistem Informasi Akuntansi, Edisi keenam, Terjemahan Amir Abadi Jusuf, Rudi M. Tambunan, Salemba Empat, Buku Satu, Jakarta

Brady, M., \& Loonam, J. (2010). Exploring the use of entity-relationship diagramming as a technique to support grounded theory 
inquiry. Bradford: Emerald Group Publishing

Cushman, P. K., \& Mata-Toledo, R. A. (2007). Dasar-Dasar Database Relasional. Jakarta: Erlangga

Hakim, Lukmanul dan Musalini, Uus. 2004. Cara Cerdas menguasai Layout, Desain dan Aplikasi Web. Jakarta. Penerbit PT. Elex Media Komputindo

Husein Umar, 2004, "Metode Penelitian Untuk Skripsi dan Tesis Bisnis", Jakarta, Raja Grafindo Persada

Jogiyanto. 2005. Analisis dan Desain Sistem Informasi. Yogyakarta: Penerbit Andi

Menurut Kertahadi (Fatta, 2007) sistem informasi adalah suatu alat yang dibutuhkan informasi

Pressman, R.S. 2015. Rekayasa Perangkat Lunak: Pendekatan Praktisi Buku I. Yogyakarta: Andi

Raharjo,Suwanto. (2004), Teori, Analisa, dan Implementasi Jaringan Tanpa Disk ,pada GNU/Linux, Andi, Yogyakarta

Solikin, I. (2016). Membangun Sistem Pengolahan Data Servis Elektronik pada Jasa Servis Toko Ria Kencana Ungu (RKU) Palembang. Jurnal Cendikia, 12(2), 1-6

\section{Solikin, I. (2017). DESAIN APLIKASI PEDATAAN PASIEN PADA PUSKESMAS TUGU JAYA KABUPATEN OKI. Jurnal Betrik, 12(3), 166-174}

Sobri, M., \& Suyanto, S. (2016). Aplikasi Pengolahan Data Administrasi Berbasis Web Studi Kasus Sekolah Dasar Negeri 16 Kayuagung. SEMNASTEKNOMEDIA ONLINE, 4(1), 1-4
Seprina, I., \& Sobri, M. (2016). Perancangan Aplikasi Pengolahan Data Administrasi Tugas Akhir Mahasiswa Berbasis Web. Jurnal Manajemen Informatika, 2(2), 43-53

Sutanta, Edhy. 2009. Sistem informasi manajemen. GRAHA ILMU : Yogyakarta

Sutanta, Edhy. Basis Data dalam Tinjauan Konseptual. Yogyakarta: Andi, 2011

Sutanta, Edhy, 2011, Basis Data dalam Tinjauan Konseptual, Penerbit Andi, Yogyakarta

Sutarman. 2012. "Buku Pengantar Teknologi Informasi". Jakarta: Bumi Aksara

Sugiyono. 2006. Metode Penelitian Kuantitatif Kualitatif dan R\&D. Bandung: Alfabeta

Tata Sutabri. 2005. Analisis Sistem Informasi. Andi. Yogyakarta

Wijaya, A. (2007). Penggunaan DFD dan ERD pada analisis dan perancang sistem informasi penjualan suku cadang dan pelayanan service pada PT. Mitra Maju Mobilindo. Jurnal teknik industri : media keilmuan dan kaitan aplikasi bidang teknik industri 
Imam Solikin, Muhammad Sobri dan Riky Adi Saputra 